Academic City University College - Accra Ghana

Society for Multidisciplinary \& Advanced Research Techniques (SMART) Africa

Tony Blair Institute for Global Change

FAIR Forward - Artificial Intelligence for All - Deutsche Gesellschaft für Internationale Zusammenarbeit (GIZ) GmbH

Accra Bespoke Multidisciplinary Innovations Conference (ABMIC)

\& The Africa Al Stakeholders' Summit

$14^{\text {th }}$ December, 2021

\title{
Influence of Principal and Parental Relationships on Teachers' Job Performance in Senior Secondary Schools in Adamawa State, Nigeria
}

1Hassan, H. K., ${ }^{2 B a m b i, ~ B . ~ I . ~ \& ~}{ }^{3}$ Bakari, H. B.

Department of Physical Sciences Education

Modibbo Adama University, Yola, Adamawa State, Nigeria

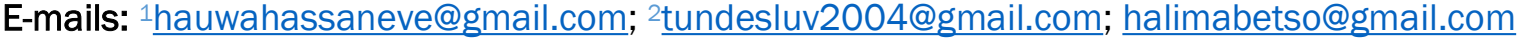

Phones: +2348036200904; +2348063462190; ${ }^{3+2347063313920}$ 


\title{
Influence of Principal and Parental Relationships on Teachers' Job Performance in Senior Secondary Schools in Adamawa State, Nigeria
}

\author{
Hassan, H K., Bambi, B I. \& Bakari, H.B.
}

\section{ABSTRACT}

This study investigated the influence of principal and parental relationships on teacher's job performance in senior secondary schools in Adamawa State, Nigeria. Three research questions and two hypotheses were formulated and tested at 0.05 level of significance. The study adopted an ex post facto research design. The population of the study was 5,458 school personnel in the senior secondary schools in Adamawa state, which were made up of 337 principals and 5,121 teaching staff as distributed over the five education zones of Adamawa state, Nigeria. The sample of the study was 374 school personnel (340 teachers and 34 principals). This was arrived at using the Taro Yamane formula. The sample was determined through multistage sampling technique that comprised of stratified random sampling and simple random sampling techniques. Influence of Principal and Parental Relationship on Teachers' Job Performance Questionnaire (IPPRTJPQ) was used for the collection of data. The data collected were analysed using mean and standard deviation to answer the research questions, Z-test for testing the hypotheses. The research question findings indicated that teachers were found to relate to a high extent with principals in senior secondary schools in Adamawa state. Also, that the relationship between teachers and parents is to a moderate extent in senior secondary schools in Adamawa state. The hypotheses findings also revealed that there is a significant influence of teacher - principal relationship on teacher's job performance with $(p=0.000<0.05)$; and also that there is a significant influence of teacher - parent relationship on teacher's job performance in senior secondary schools in Adamawa State with $(p=0.000<0.05)$. Based on the findings; it was concluded that teachers' relationship with principals and parents significantly influence their job performance in senior secondary schools in Adamawa state, Nigeria. The study recommended that principals and teachers in senior secondary schools need to relate positively amongst themselves irrespective of their demographic differences which can help to improve their teaching performance either on a personal or professional level.

Keywords: Teacher-Principal Relationship; Teacher-Parent Relationship; Teachers' Job Performance; Senior Secondary School; Adamawa State

\section{INTRODUCTION}

Education is severally conceived and inculcated by people of varying backgrounds, ages, needs and aspirations for sustainable development. The potency of education is more evident in its globalization trends imbued with instrumental values of nurturing productive citizens for sustainable development and democracy (Ogunyinka, Okeke \& Adedoyin, 2015). Education has been recognized as a process of imparting knowledge, skills and attitudes to the learners and to accomplish this, a lot of interactions should occur between the teacher and the students. As teachers are saddled with the responsibilities of moulding students towards educational excellence (Chamundeswari, 2013), the teacher builds up different interpersonal relationships (i.e. with his students, colleagues, superiors/principal and the student's parent) before this goal can be achieve. 
Interpersonal relationship generally refers to a connection or association between two or more people. According to Obakpolo (2015), interpersonal relationship at work constitutes the day to day interaction between co-workers, or managers and employees. These relations are a natural part of the work environment and are usually pleasant and creative, but sometimes the source of tension and frustration may occur. According to Yemi (2012) interpersonal relationship within a school system involves all forms of interactions between the students, teachers, students to teacher, students to principal, teachers to principal, teachers to parent and principal to parents that occurs within the school. Teachers, who are the focus of this study link together students, teachers, school administrators, families and community members to foster learning and healthy development of their students (Wang \& Haertel, 1996). In doing so, the teacher forms a bond with the remaining school agents that could motivate the teacher in performing his best towards achieving the school goals.

In identifying the role played by teacher - principal relationship in influencing teachers' job performance, the principal's leadership style comes to mind. The principal leadership style is principal's behaviour in a working process, which influences school performances. The principal creates his/her management style through education, training and personal development (Spector in Chamundeswari, 2013); the teacher provides creative working environment and positive climate in school. Horng, Kalogrides and Loeb (2009) also opined that effective principals' leadership style influences a variety of school outcomes. This includes students' achievement, recruitment of quality teachers, effective allocation of resources, and use of school structures to support instruction and learning. To achieve this however, the principal banks on building positive relationships with teachers. It is apparent in most schools that a bond of trust, respect, and mutual support must be present between the principal and the teachers for student achievement to prosper. These are vested on teachers' job performance (Van Beck, 2011).

However, principal-teacher relationships vary greatly among schools and even among teachers at the same school. Furthermore, those relationships affected teachers' job performance as well as student achievement (Edgerson \& William, 2006). This phenomenon occurs because teachers who see principals as facilitators, supporters, and re-inforcers for the jointly determined school mission rather than as guiders, directors, and leaders of their own personal agenda are far more likely to feel personally accountable for student learning. Principals, therefore have the ability to improve teachers' job performance through establishing quality professional relationships, showing personal support for teachers, good social interactions, pastoral care, rewards and recognition (Greenstreet, 2010).

Teacher - parent relationship refers to the mutual respect that exists between teachers and their students' parents. Maharaj-Sharma (2003) noted that parents see teachers as their children's "other parents" and as a result are worried about the influence teachers have on them. Teachers on the other hand, see parents as the "other teachers" and are also worried about the students' home environment and parents' concern over their disciplinary actions. Parents suffer if the teacher-student relationship is bad; teachers suffer if the parent-child relationship is bad. Each has a stake in the relationship that the child has with the other party. Despite this mutual interest in each other's behaviour, parents and teachers seldom have a very close or significant relationship with each other. 
For clarity purpose, the Teachers Registration Council of Nigeria, TRCN (2005) stipulated the kind of relationship that should exist between teachers and parents such as; right to information, regular communication, mutual respect, participation in Parents Teachers Association (PTA) and avoid favouritism. The influence of this relationship on teachers' job performance is when parents fail to properly carry out their own obligations or seek more than the norm. Also, teachers' expectations of favours from parents could cloud their judgments on students' performance, while deteriorating their own job performance.

Obi (2013) defined teacher's job performance as duties performed by a teacher at a particular period in the school system in achieving organizational goals. Fadeyi, Sofoluwe and Gbadeyan (2015) described teachers' job performance as the ability of teachers to combine relevant inputs for the enhancement of teaching and learning processes in their schools. These assertions show that teachers' job performance refers to the contribution of a teacher's mental and physical ability towards the achievement of the school's objectives. Teacher's job performance plays a crucial role in student's learning process. Teachers play a basic and dynamic role in the educational system. It is said that good performance of students depends upon effective teaching of their teachers. As professionals, teachers should display their role models skill at all times and exhibit to their students a commitment to scholarly values and to life-long learning (Shannon, 2012). Cheng (2010) posited that teachers' job performance could be measured through job satisfaction that influence job attitudes such as job commitment, job meaningfulness and job responsibility. When one is satisfied, one's job performance might increase and one tends to be more committed to the work. Job performance is therefore important to ensure the quality of instruction taking place at school.

Although, Atiya and Palawasha (2012) noted that some other factors contribute to low level of teachers' job performance in secondary schools. These include inadequate pay, poor career structure, poor school facilities, inadequate school disciplinary policy, principal's leadership behaviour and students' poor work attitudes and teachers' behaviour. Chamundeswari (2013) posited that performance of teachers mainly depends on the teacher characteristics such as knowledge base, sense of responsibility, and inquisitiveness. The student characteristics such as opportunity to learn and level of academic work are also a factor. Teaching factors such as lesson structure and communication and the learning aspects such as involvement and successes are also a factor with the classroom phenomena such as climate, organization and management. All these simply point out to the various school factors that surround the teacher in the discharge of his/her duty. In the context of this study, interpersonal relationship as an influence on teachers' job performance is been delimited to teachers' relationship with the school principal and parents in senior secondary schools in Adamawa state.

This study was carried out in Adamawa State, where personal observations have shown that most teachers engaged in different illicit practices within and outside the school at the expense of their performances and students' academic achievement. Çağrı (2013) noted that among the factors that decide teachers' commitment and performance include: interaction between teachers, teacher-student relationship, the quality of the work teachers do at school, the compatibility of school administration. Yemi (2012) and Ogundele (2014) in agreement posited that infighting among teachers, poor relationship between some teachers and principals and even the students' parents are common school factors that have derailed teachers' job performance in some schools in Nigeria. As a consequence, the researchers designed this study to investigate how principal and parental relationships influence teachers' job performance in senior secondary schools in Adamawa state. 


\subsection{Problem Statement}

There is no gainsaying today that the teachers' job suffers a lot of personnel management issues that ranges from high turnover, poor welfare, poor socio-economic status, poor performance and poor commitment to indiscipline. Chief among these issues is poor teachers' job performance. Empirical evidence and further observations by the researcher also reveal that government's investment on education and public students' academic achievements do not correspond well, especially in Adamawa state. Although many researchers (Melor, Wan Safura \& Noriah, 2011; Yemi, 2012; Obakpolo, 2015 to count a few) have pointed at various school factors such as teachers' professional development, welfare packages, physical facilities, instructional materials, principal's leadership skills, students' home environment and parental level of involvement as factors influencing teachers' job performance. Fewer studies have highlighted the role played by interpersonal relationships on teachers' high or low job performance. The problem stated here is, how do principal and parental relationships influence teachers' job performance in Adamawa state?

In studying how principal and parental relationships influence teachers' job performance in Adamawa state; the researcher observed that students sometimes deliberately frustrate the work of a teacher, if there is a negative interaction between them; while the attitude of a teacher may add to unwanted classroom problems with students, which may also affect their job performance. Thereby causing a chaos when principals or a representative comes for supervision. In addition, the lack of support from the school principal either on personal or professional grounds could also influence teachers' job performance positively or negatively. On the other hand, parental relationship with teachers are often interwoven, as both parties worry about the other's role in the life of the child. The kind of support (positive or negative), a teacher receives from his/her students' parent can influence their job performance.

From the foregoing, it is clear that principal and parental relationships in schools influence teachers' job performance. However, the extent to which it exhibit significant influence on Adamawa state teachers' job performance is what remains unclear. And the dearth of material especially in this study are makes the study relevant. Thus, this study was specifically set up to investigate how principal and parental relationships influence teachers' job performance in senior secondary schools in Adamawa state, Nigeria.

Specifically, the study sought to;

1. Assess the influence of interpersonal relationship between teachers and principals on teachers' job performance in Senior Secondary Schools in Adamawa State.

2. Assess the influence of interpersonal relationship between teachers and parents on teachers' job performance in Senior Secondary Schools in Adamawa State.

3. Assess the extent to which teachers' perform their jobs in senior secondary schools in Adamawa state.

\subsection{Research Questions}

The following research questions were raised and answered in this study;

1. How does interpersonal relationship between teachers and principals influence teachers' job performance in Senior Secondary Schools in Adamawa State?

2. How does interpersonal relationship between teachers and parents influence teachers' job performance in Senior Secondary Schools in Adamawa State?

3. To what extent do teachers perform their jobs in senior secondary schools in Adamawa state? 


\subsection{Hypotheses}

The following null-hypotheses were formulated and tested at 0.05 level of significance in this study;

Ho1: There is no significant influence between teachers - principal relationship and teachers' job performance in Senior Secondary Schools in Adamawa State;

Ho2: $\quad$ There is no significant influence between teachers - parent relationship and teachers' job performance in Senior Secondary Schools in Adamawa State.

\subsection{Theoretical Framework}

The theoretical framework of this study is based on Moolenaar's (2012) Social Network theory. This theory was propounded by Nienke M. Moolenaar in 2012 to understand the complex role of teacher relationships in improving teaching and learning and in facilitating educational change. Generally, the social network theory in education comes from two perspectives; the first stream of social network research in education examines teacher collaboration by analysing networks across schools or districts and the second stream of social network research in education aims to understand teacher collaboration by analysing social networks within schools or districts (Moolenaar, 2012).

Moolenar's (2012) social network theory on teachers' collaboration in schools focused on the second perspective. Social networks in this sense can be regarded as patterns of relationships that reflect purposive interaction among educators in a bounded group, such as grade levels, subject matter departments, or schools. Studies interested in such networks often focus on how patterns of relationships among educators within schools or districts affect teachers' instructional practice, student learning, or the implementation of reforms. From a review of social network studies in education, Moolenaar identified at least five key findings on schools' network structure that appear to hold across studies.

1. Social network structure differs across schools: There are considerable differences between schools with regard to their internal social network structure as previous work by Moolenaar, Daly and Sleegers (2010) suggested that there is variability between schools in the extent to which teachers interact with each other. On average, teachers were found to interact with about a third of their colleagues around work-related matters such as work discussions, collaboration, and advice.

Yet, the number of relationships varied from $10 \%$ in some schools to about $77 \%$ in others. In addition, networks may be more centralized around a few influential, informal leaders in some schools than in others. For instance, the same studies in Dutch schools found considerable variation in the extent to which principals occupy a central position in their school's advice network, resulting in differences in the influence they have on the system through direct advice relationships with teachers (Moolenaar, 2010).

2. Schools' overall network structure is often fragmented, resulting in subgroups: Teachers' relationships are often structured in subgroups within the overall pattern of teacher relationships in schools. Social network theory offers two mechanisms that may explain why teachers cluster together in subgroups-namely, structural balance and homophile (Davis in Moolenaar, 2012).

According to Moolenaar (2012) structural balance refers to the phenomenon that individuals are more likely to create new strong, direct ties with friends of friends and discontinue weaker relations with friends of enemies and enemies of friends, arguably in order to reduce psychological discomfort arising from cognitive dissonance. 
Subgroups may also emerge as a result of the principle of homophile, which asserts that individuals tend to form relationships based on how similar they are; for instance, with regard to age, gender, or educational level. The more similar individuals are, the more quickly resources will flow among these individuals. The converse is also true in that dissimilar individuals are less likely to share resources (Frank, Chong \& Belman, 2010)

3. Schools' social network structure often deviates from formal hierarchical structure: The formal structure of schools that is, the way in which formal roles such as principal, coach, and teacher are organized is often not fully aligned with the pattern of social relationships among educators in schools (Spillane \& Healey, 2010). For instance, in some schools coaches, subject area leaders, and administrators were found to play only a peripheral role in the advice networks of teachers, even though they were formally appointed to support teachers in making instructional changes (Frank et el, 2010).

4. Social networks serve multiple purposes and are shaped accordingly: The content of social relationships matters for the ways in which social networks are structured. Teachers interact for different purposes in order to meet the intellectual, emotional, and social demands of teaching (Davis, 1963) and the resulting networks tend to overlap, as beneficial work relationships may develop into stronger personal relationships (Moolenaar, 2012).

A common distinction based on the content of relationships is made between instrumental and expressive relationships. Moolenaar (2012) explained that instrumental relationships refer to work-related relationships that are ultimately targeted at achieving school goals, such as the exchange of instructional materials etc. Expressive relationships refer to more affective-laden relationships that are not directly aimed at work-related issues and that often place the individual's interest above that of the organization, such as friendship and personal guidance (Spillane \& Healey, 2010). In general, expressive ties are believed to be stronger, more durable, and trustworthy than instrumental relationships.

5. Social networks are shaped by various individual and school characteristics: There are various characteristics of individuals and schools that appear to affect the social network structure in schools. The previous principle of homophile is well studied and explains how social networks are shaped by similarities among teachers. Findings show that teachers are more likely to interact with teachers who are similar to them with regard to gender, age, experience, ethnicity, grade level, subject matter, physical proximity, beliefs about teaching, and prior professional relationships (Moolenar, 2010 \& Frank et. el., 2010).

Moreover, the way in which a school is formally organized (grade level teams, cross-grade-level teams and interdependent teaching roles) and the amount of shared experience as a team affects the pattern of social relationships among educators (Moolenaar et. el. 2010).

In summary, Moolenaar (2012) five findings offer a brief overview of current knowledge on the structure and properties of social networks (i.e. teacher relationships) in schools. This theory was chosen because of its close relationship to the independent variable (i.e. principal and parental relationship) and the revelation that on how school teachers relate, superiors and their students' parent for collaboratively work on a shared school goal, which directly or indirectly influence their job performance. 


\section{METHODOLOGY}

The study used an ex post facto research design to guide the study. The area of the study was Adamawa state. The target population of the study was 5,458 school personnel in the senior secondary schools in Adamawa state. The population was made up of 337 principals and 5,121 teaching staff as distributed over the five education zones of Adamawa state, Nigeria. In order to ensure that the characteristics of the population are well represented in the sample, Taro Yamane formula was used to calculate the sample with 95\% confidence level. The sample size of 374 school personnel was obtained and was therefore selected using multistage sampling technique that comprised of stratified and simple random sampling technique.

The study used a questionnaire as the instrument for data collection. The questionnaire was tagged 'Influence of Principal and Parental Relationship on Teachers' Job Performance Questionnaire (IPPRTJPQ)" and has 36 test items. The questionnaire that was used to collect data was used to answer the research questions and had different items with each item given options in a five Likert response scale letters; "VHE" for Very High Extent, "HE" for High Extent, "ME" for Moderate Extent, "LE" for Low Extent and "VLE" for Very Low Extent. These letters were assigned values as 5,4,3,2, and 1 respectively with five (5) as the highest score, standing for VHE and one (1) as the lowest score representing VLE.

Three research experts from the department of Physical Sciences Education from Modibbo Adama University, Yola validated the research instrument. The instrument was trial tested to 33 copies of the questionnaire were administered to 3 principals and 30 teachers in three senior secondary schools that were not part of the sampled population in Adamawa state. Cronbach Alpha method was used to determine the reliability of the instruments used in the study. The overall reliability co-efficient obtained for IPPRTJPQ was 0.86 ; which meant the instrument was reliable. At the end of the data collection exercise, 359 copies of the questionnaires were retrieved representing $95.9 \%$ of the total questionnaire administered. At the time of tallying the results, 346 valid copies of the questionnaire were obtained, which was $92.5 \%$ of the total questionnaire.

The research questions were answered using Mean and Standard Deviation; while Z-test Analysis was used to test the hypotheses at significance level of 0.05 . The decision rule for the research questions were determined using the real limits of numbers as follows; 4.5 - 5.00 was accepted as "VHE", 3.50 - 4.49 was accepted as "HE", 2.5 - 3.49 was accepted as "ME", 1.5 - 2.49 was accepted as "LE" and $0-1.49$ was accepted as "VLE". While the decision rule for the hypothesis was reached when the $p$-value exceeds the level of significance of 0.05 , the null hypotheses raised was rejected and the study concluded that the variable significantly influence the dependent variable. 


\section{RESULTS}

Research Question 1: How does interpersonal relationship between teachers and principals influence teachers' job performance in Senior Secondary Schools in Adamawa State?

Table 1: Mean and standard deviation on the extent of teacher - principal relationship in senior secondary schools in Adamawa State

\begin{tabular}{clcccc}
\hline S/N & ITEMS & $\mathrm{n}$ & Mean & S.D & Remark \\
\hline 7. & Principal's show of mutual respect & 346 & 3.23 & 0.84 & $\mathrm{ME}$ \\
8. & Principal's leadership style & 346 & 3.63 & 1.09 & $\mathrm{HE}$ \\
9. & Principal's social interaction & 346 & 3.59 & 1.11 & $\mathrm{HE}$ \\
10. & Principal's professional support & 346 & 3.87 & 1.06 & $\mathrm{HE}$ \\
11. Principal's personal support & 346 & 3.51 & 1.17 & $\mathrm{HE}$ \\
12. & Principal's recognition of work done & 346 & 3.17 & 1.20 & $\mathrm{ME}$ \\
& Grand Mean & & 3.50 & 1.03 & $\mathrm{HE}$ \\
\hline
\end{tabular}

Key: S.D = Standard Deviation; HE = High Extent; ME = Moderate Extent

In table 1 , the grand mean is 3.50 which is an indication that the relationship between teachers and principals is to a high extent in senior secondary schools in Adamawa state.

Research Question 2: How does interpersonal relationship between teachers and parents influence teachers' job performance in Senior Secondary Schools in Adamawa State?

Table 2: Mean and standard deviation on the extent of teacher - parent relationship in senior secondary schools in Adamawa State

\begin{tabular}{|c|c|c|c|c|c|}
\hline $\mathrm{S} / \mathrm{N}$ & ITEMS & $\mathrm{n}$ & Mean & S.D & Remark \\
\hline 13. & Show of mutual respect & 346 & 3.51 & 1.25 & $\mathrm{HE}$ \\
\hline \multirow{2}{*}{$\begin{array}{l}14 . \\
15 .\end{array}$} & Parents' attitude towards students' assignment & 346 & 2.80 & 1.16 & ME \\
\hline & $\begin{array}{l}\text { Parents' general involvement with students' } \\
\text { education }\end{array}$ & 346 & 3.50 & 1.20 & $\mathrm{HE}$ \\
\hline 16. & Parents' co-operation on disciplinary issues & 346 & 3.25 & 1.25 & $\mathrm{ME}$ \\
\hline 17. & Parents' feedback on students & 346 & 3.23 & 1.19 & ME \\
\hline \multirow[t]{2}{*}{18.} & Gifts received from parents & 346 & 2.76 & 1.30 & ME \\
\hline & Grand Mean & & 3.18 & 1.19 & ME \\
\hline
\end{tabular}

Key: S.D = Standard Deviation; HE = High Extent; ME = Moderate Extent

In table 2, the grand mean is 3.18 which is an indication that the relationship between teachers and parents is to a moderate extent in senior secondary schools in Adamawa state. 
Research Question 3: To what extent do teachers perform their jobs in senior secondary schools in Adamawa state?

Table 3: Mean and standard deviation on the extent to which teachers perform their jobs in senior secondary schools in Adamawa state

\begin{tabular}{|c|c|c|c|c|c|}
\hline $\mathrm{S} / \mathrm{N}$ & ITEMS & $\mathrm{n}$ & Mean & S.D & Remark \\
\hline 19. & Teachers' regular preparation of daily lesson notes & 346 & 3.20 & 1.22 & $\mathrm{ME}$ \\
\hline 20. & Teachers' regular use of lesson plans in class activities & 346 & 3.42 & 1.28 & $\mathrm{ME}$ \\
\hline 21. & Teachers' content delivery ability & 346 & 3.11 & 1.35 & ME \\
\hline 22. & Teachers' methods of teaching & 346 & 3.14 & 1.44 & ME \\
\hline 23. & Teachers' submissiveness to their heads & 346 & 3.02 & 1.25 & $\mathrm{ME}$ \\
\hline 24. & Teachers' use of termly scheme of work & 346 & 3.23 & 1.12 & ME \\
\hline 25. & $\begin{array}{l}\text { Teachers' active involvement in co-curricular activities } \\
\text { in school }\end{array}$ & 346 & 3.53 & 1.31 & $\mathrm{HE}$ \\
\hline 26. & $\begin{array}{l}\text { Teachers' effective management of students' discipline } \\
\text { in school }\end{array}$ & 346 & 3.41 & 1.32 & ME \\
\hline 27. & Teachers' regular attendance to all lessons & 346 & 2.96 & 1.08 & ME \\
\hline 28. & Teachers' regular assessment of students through tests & 346 & 3.48 & 1.13 & ME \\
\hline 29. & Teachers' efficient counselling and guidance of students & 346 & 3.44 & 1.14 & $\mathrm{ME}$ \\
\hline 30. & Teachers' maintenance of students' records & 346 & 3.52 & 1.19 & HE \\
\hline 31. & Teachers' effective participation in staff meetings & 346 & 3.21 & 1.14 & $\mathrm{ME}$ \\
\hline 32. & Teachers' role as model to their students & 346 & 3.47 & 1.22 & $\mathrm{ME}$ \\
\hline 33. & Teachers' ability to ensure safety in the class & 346 & 3.75 & 1.13 & HE \\
\hline 34. & Teachers' classroom management & 346 & 3.42 & 1.12 & ME \\
\hline 35. & Teachers' time management & 346 & 3.34 & 1.37 & ME \\
\hline 36. & Teachers' ingenuity & 346 & 3.16 & 1.28 & ME \\
\hline 37. & Teachers' resourcefulness & 346 & 3.07 & 1.29 & ME \\
\hline 38. & Teachers' updating of knowledge & 346 & 3.00 & 1.21 & ME \\
\hline 39. & Teachers' punctuality to school & 346 & 3.03 & 1.28 & ME \\
\hline 40. & Teachers' adherence to school policy & 346 & 3.27 & 1.22 & ME \\
\hline 41. & Teachers' ability to initiate actions & 346 & 3.17 & 1.34 & ME \\
\hline 42. & Teachers' overall personality & 346 & 3.17 & 1.23 & ME \\
\hline & Grand Mean & & 3.27 & 1.20 & ME \\
\hline
\end{tabular}

Key: S.D = Standard Deviation; HE = High Extent; ME = Moderate Extent

In table 3 , the grand mean is 3.27 which is an indication that teachers perform their job to a moderate extent in 


\section{Research Hypotheses:}

Ho1: There is no significant influence between teacher - principal relationship and teachers' job performance in Senior Secondary Schools in Adamawa State.

Table 4: Z-test Analysis showing Influence of Teacher - Principal Relationship and Teachers' Job Performance

\begin{tabular}{cccccccc}
\hline Variables & $\mathrm{n}$ & $\overline{\mathrm{X}}$ & $\mathrm{SD}$ & $\mathrm{df}$ & $\mathrm{Z}$ & $\mathrm{sig}$ & Decision \\
\hline Teacher-Principal Relationship & 346 & 3.50 & 1.03 & & & & \\
& & & & 690 & -36.35 & 0.000 & Reject \\
Teacher's Job Performance & 346 & 3.27 & 1.20 & & & & \\
\hline
\end{tabular}

Key: $\bar{X}=$ Mean; S.D = Standard Deviation; $d f=$ degree of freedom;

Table 4 shows the z-test analysis of the influence of teacher-principal relationship on teacher's job performance. Since $\mathrm{p}=0.00<0.05$, the null hypothesis $\left(\mathrm{Ho}_{3}\right)$, is therefore rejected. This means that there is a significant influence of teacher-principal relationship on teacher's job performance in senior secondary schools in Adamawa State.

Ho2: $\quad$ There is no significant influence between teachers - parent relationship and teachers' job performance in Senior Secondary Schools in Adamawa State

Table 5: Z-test Analysis showing Influence of Teacher - Parent Relationship and Teachers' Job Performance

\begin{tabular}{cccccccc}
\hline Variables & $\mathrm{n}$ & $\overline{\mathrm{X}}$ & $\mathrm{SD}$ & $\mathrm{df}$ & $\mathrm{Z}$ & sig & Decision \\
\hline Teacher-Parent Relationship & 346 & 3.18 & 1.19 & & & & \\
& & & & 690 & -37.31 & 0.00 & Reject \\
Teacher's Job Performance & 346 & 3.27 & 1.20 & & & & \\
\hline
\end{tabular}

Key: $\bar{X}=$ Mean; S.D = Standard Deviation; $d f=$ degree of freedom;

Table 5 shows the z-test analysis of the influence of teacher-parent relationship on teacher's job performance. Since $p=0.00<0.05$, the null hypothesis $\left(\mathrm{Ho}_{4}\right)$, is therefore rejected. This means that there is a significant influence of teacher-parent relationship on teacher's job performance in senior secondary schools in Adamawa State. 


\subsection{Major Findings of the Study}

The findings of the study are as follows;

5. The relationship between teachers and principals is to a high extent in senior secondary schools in Adamawa state, with a grand mean of 3.50.

6. The relationship between teachers and parents is to a moderate extent in senior secondary schools in Adamawa state, with a grand mean of 3.18.

7. Teachers perform their job to a moderate extent in senior secondary schools in Adamawa state, with a grand mean of 3.27.

8. There is a significant influence of teacher - principal relationship on teacher's job performance in senior secondary schools in Adamawa State with $(p=0.000<0.05)$.

9. There is a significant influence of teacher - parent relationship on teacher's job performance in senior secondary schools in Adamawa State with $(p=0.000<0.05)$.

\section{DISCUSSION OF FINDINGS}

This study also found that teachers relate to a high extent with principals in senior secondary schools in Adamawa State (with a grand mean of 3.50). This finding concurred with Gray (2013); Josanov-Vrgovic and Nebojsa (2014) and Babaoglan's (2015) findings that teachers and principals relate on a daily basis as it is necessary for the achievement of the school goals and objectives. However, the findings disagree with that of Johnson (2008); Van Beck (2011) and Godfred (2013) whose study revealed most teachers and principals do not relate highly in schools. Their relationships most at times do not go beyond the required morning and closing greetings. The findings also revealed that there is a significant influence of teacher - principal relationship on teacher's job performance in senior secondary schools in Adamawa state with $(p=0.000<0.05)$.

The finding was in line with Korb and Akintunde (2013), Singh and Bleema (2014), that there is a strong relationship between teachers and principals, which is a requirement for effective teacher performance in classrooms. These then translates into the enhancement of principals' ability to improve teachers' job performance through establishing quality professional relationships, showing personal support for teachers, good social interactions and pastoral care, rewards and recognition.

This study also found that; teachers relate to a moderate extent with parents in senior secondary schools in Adamawa State (with a grand mean of 3.32). This finding concurred with Tan and Goldberg (2009); Sabine, Chiara, Ylenia and Traute (2013) and Ozmen, Akuzum, Zincirli and Selcuk's (2016) findings that teachers and parents strong relationship can be used for enhancing students' academic performances and ultimately teachers' job performance in secondary schools. Although, the findings disagree with that of Evans (2004 and Ellis (2012)'s study that discovered that teachers and parent do not relate effectively in secondary schools as most at times; they had different perspectives on school expectations thereby preferring to work on an individual level. There is a significant influence of teacher - parent relationship on teacher's job performance in senior secondary schools in Adamawa State with $(p=0.000<$ 0.05). 
The finding was in line with Sabine, Chiara, Ylenia and Traute (2013) and Singh and Bleema's (2014) study who found out that there is a significant relationship between teacher - parent relationship and teachers' job performance. Hence, schools should adopt an open-door policy for parents as this will encourage them to show more interest in their children's academics, by relating more with teachers and trusting their works; which may spur teachers on to continually give their best during instruction.

\section{CONCLUSION}

Based on the findings of this study, it was concluded that principal and parental relationship significantly influence teachers' job performance in senior secondary schools in Adamawa state, Nigeria.

The study however recommends the following;

1. School principals also need to establish more positive approach in dealing with the individual differences that exist between their teaching staff as this could help drive them towards a more positive job performance in schools.

2. Principals and teachers needs to relate positively amongst themselves irrespective of their demographic differences which can help to improve their teaching performance either on a personal or professional level.

3. Parents are also encouraged to develop more positive relationship with their children's teachers in senior secondary schools either through their participation in school programmes when necessary or helping their children with school assignments as this has a positive effect on not only teachers' performances but also could rub on their children's academic performances. 


\section{REFERENCES}

1. Atiya, I. \& Palwasha, J. (2012). Teacher's job performance: The role of motivation. Abasyn Journal of Social Sciences, 5(2), 78 - 99.

2. Babaoglan, E. (2015). Improving principal and teacher relationship: predictive power of school principals' leadership with teachers' organizational trust perception. Educational Planning, 23(2), 7 - 17.

3. Çağrı, T. M. (2013). A passionate teacher: Teacher commitment and dedication to student learning. International Journal of Academic Research in Progressive Education and Development, 2(1), 437 - 442.

4. Chamundeswari, S. (2013). Job satisfaction and performance of school teachers. International Journal of Academic Research in Business and Social Sciences, 3(5), 420 $-428$.

5. Cheng, M. A. (2010). Impact of organizational climate on performance of college teachers in Punjab. Journal of College Teaching \& Learning, 7(10), 47 - 52.

6. Davis, J. A. (1963). Structural balance, mechanical solidarity, and interpersonal relations. American Journal of Sociology, 68, 444 - 462.

7. Edgerson, D. E. \& William, A. K. (2006). Analysis of the influence of principal -teacher relationships on student academic achievement: a national focus. National Journal for Publishing and Mentoring Doctoral Student Research, 1(1), 123 - 131.

8. Ellis, M. K. (2012). Parent-teacher interactions: A study of the dynamics of social influence. (PhD. Thesis: Edith Cowan University, Australia).

9. Evans, R. (2004). Talking with parents today. Independent School, 63(3), 96 - 100.

10. Fadeyi, V. T., Sofoluwe, A. O. \& Gbadeyan, A. K. (2015). Influence of teachers' welfare scheme on job performance in selected Kwara state secondary schools. Asia Pacific Journal of Education, Arts and Sciences, 2(4), 89 - 93.

11. Federal Republic of Nigeria (2013). National policy on education. Lagos: NERDC.

12. Frank, K. A., Chong, M. K. \& Belman, D. (2010). Utility theory, social networks, and teacher decision-making: modeling networks' influences on teacher attitudes and practices. In A. J. Daly (ed) Social Network Theory and Educational Change. Cambridge, MA: Harvard University Press.

13. Godfred, G. (2013). Principal - teacher relationship in leading school. Master's Thesis: University of Jyvaskla.

14. Greenstreet, P. (2010). The key elements of positive relationships between principal and staff in primary schools. Term 3, Coatesville School Principal's Sabbatical Report.

15. Horng, E. L., Kalogrides, D. \& Loeb, S. (2009). Principal preferences and the uneven distribution of principals across schools, CALDER Working Paper 36. Washington, DC: The Urban Institute.

16. Johnson, D. F. (2008). In Van Beck, S. A. (2011). The importance of the relationships between teachers and school principals. (Ph.D. Thesis: University of Houston).

17. Josanov-Vrgovic, L. \& Nebojsa, P. (2014). Relationship between the school principal leadership style and teachers' job satisfaction in Serbia. Montenegrin Journal of Economics, 10(1), 43 - 57.

18. Korb, K. A., \& Akintunde, O. O. (2013). Exploring factors influencing teacher job satisfaction in Nigerian schools. Nigerian Journal of Teacher Education and Training, $11,211-223$. 
19. Maharaj-Sharma, R. (2003). Are parents doing it right? School of Education, UWI, St. Augustine.

20. Melor, M. Y., Wan Safuraa, W. O. \& Noriah, M. I. (2011). Teacher-student relationship factor affecting motivation and academic achievement in ESL classroom. Procedia Social and Behavioural Sciences, 15, 2637 - 2641.

21. Moolenaar, N. M. (2010). Ties with potential: Nature, antecedents, and consequences of social networks in school teams. (PhD Thesis: University of Amsterdam).

22. Moolenaar, N. M. (2012). A social network perspective on teacher collaboration in schools: Theory, methodology, and applications. American Journal of Education 119, 7 $-39$.

23. Moolenaar, N. M., Daly, A. J. \& Sleegers, P. J. C. (2010). Occupying the principal position: Examining relationships between transformational leadership, social network position, and schools' innovative climate. Educational Administration Quarterly, 46, 623 - 670.

24. Obakpolo, P. (2015). Improving interpersonal relationship in workplaces. IOSR Journal of Research \& Method in Education (IOSR-JRME), 5(6), 115 - 125.

25. Ogundele, M. O. (2014). Teachers' job satisfaction and job performance of secondary schools in Kwara State. International Journal of Research, 1(11), 56 - 62.

26. Ogunyinka, E. K., Okeke, T. I., \& Adedoyin, R. C. (2015). Teacher education and development in Nigeria: An analysis of reforms, challenges and prospects. Education Journal, 4(3), 111 - 122.

27. Ozmen, F., Akuzum, C., Zincirli, M., \& Selcuk, G. (2016). The communication barriers between teachers and parents in primary schools. Eurasian Journal of Educational Research, 66, 26 - 46.

28. Post Primary School Management Board, PPSMB (2017). Number of students registered into the school system. Yola: PPSMB Document.

29. Sabine, P. Chiara, T. Ylenia, P. \& Traute, T. (2013). The role of the relationship between parents and educators for child behaviour and wellbeing. International Journal about Parents in Education, 7(2), 145 - 155.

30. Shannon, S. A. (2010). Relationship between organizational climate and performance of teachers in public and private colleges of New Zealand.

31. Singh, P. \& Bheema, M. (2014). Interpersonal relation and its effect on teaching and learning. Journal of Educational Policy and Entrepreneurial Research (JEPER), 1(2), 1 $-10$.

32. Spector, P. (1997). Job satisfaction: Application, assessment causes and consequences. In S. Chamundeswari (2013). Job satisfaction and performance of school teachers. International Journal of Academic Research in Business and Social Sciences, 3(5), $420-428$.

33. Spillane, J. P. \& Healey, K. (2010). Conceptualizing school leadership and management from a distributed perspective: an exploration of some study operations and measures. Elementary School Journal, 11(2), 253 - 281.

34. Tan, E. T. \& Goldberg, W. A. (2009). Parental school involvement in relation to children's grades and adaptation to school. Journal of Applied Developmental Psychology, 30, $442-453$.

35. Teachers Registration Council of Nigeria, TRCN (2005). Teachers' code of conduct. (Revised). Abuja: TRCN Publications. 
36. Van Beck, S. A. (2011). The importance of the relationships between teachers and school principals. Ph.D. Thesis: University of Houston.

37. Wang, M. C. \& Haertel, G. D. (1996). Teacher relationships. A digest of research from the Laboratory for Student Success.309

38. Yemi, T. O. (2012). Organisational climate and teachers' job performance in primary schools in Ondo state, Nigeria: An Analytical Survey. Asian Journal of Information Technology, 7(4), 138 - 145. 